\title{
The Metropolitan Effect: Colonial Influence on the Internationalization of Francophone African Firms
}

\section{Tah Ahmed Meouloud, Ram Mudambi, $\odot$ and TL Hill}

Temple University, USA

ABSTRACT Drawing on the experience of firms of various sizes from Francophone Africa, we explore how the internationalization trajectories of frontier economy firms may vary from those predicted by theory. The firms studied followed social, linguistic, cultural, and institutional gradients to internationalize first to France, rather than to neighboring countries, and did so in search of not only markets and resources but also legitimacy. In turn, the sales, resources, and legitimacy acquired in France supported further international expansion, sometimes even to neighboring countries. Although our insights derive from the experience of Francophone firms from Africa, we argue that for firms from all former colonies, the internationalization trajectory leads through the colonial center. Our findings underline the roles of legitimacy-seeking and network ties in the internationalization of frontier market firms and serve as a salutatory reminder of the lingering influence of colonial ties on international business.

KEYWORDS colonialism, foreign market entry, international strategy, legitimacy, social networks

\section{INTRODUCTION}

In this paper, we draw on exploratory, illustrative case studies of firms from Morocco, Tunisia, Gabon, and Senegal to explore how the African experience, especially of colonialism, changes theories about the process of internationalization. Our cases suggest that rather than following gradients of cultural and geographic proximity, or riding the coattails of MNE global value chains, firms from Francophone Africa expand first to France, following patterns of trade, social networks, transportation, education, and institutional design set during European colonialism. Specifically, these firms internationalize first to France (especially to Paris), to assemble resources and build legitimacy; they then use these resources and legitimacy to expand elsewhere, often back to neighboring countries in Africa. In other words, the internationalization trajectory for firms from Francophone Africa run through the old colonial center and from there

Corresponding author: Ram Mudambi (rmudambi@temple.edu) 
out into the world. We call the pull of, and path through, the colonial center the 'metropolitan effect' or l'effet métropolitain and argue that it shapes the internationalization process for firms in post-colonial countries.

Frontier (Fujita \& Mori, 1998) and emerging economies provide a useful context for examining the interaction between theory and context (Xu \& Meyer, 2013) because cases from such economies illustrate managerial phenomena and contexts that differ substantially from the phenomena and contexts that spawned existing theory (Barnard, Cuervo-Cazurra, \& Manning, 2017). Thus, the fact that so many African countries are mired in extreme poverty and plagued by institutional voids (Khanna \& Palepu, 2013) and underdeveloped business systems (Witt, de Castro, Amaeshi, Mahroum, Bohle, \& Saez, 2018) means that the theoretical lenses developed for research of the European and American business environments and even the refinements developed for the emerging economies of Asia may not be entirely appropriate. Specifically, as argued by De Soto (2000) and others, much of what makes capitalism work in advanced economies is the institutional infrastructure and the deep well of experience and routines that organizations and individuals draw upon. The lack of such institutions and routines in Africa make it a particularly fruitful context for testing the assumptions and boundary conditions of extant theory (George, 2015).

Scholars have highlighted the importance of local context in international business (Meyer, Mudambi, \& Narula, 2011), and the salient differences between the Western and Asian business contexts have now been studied in some detail (Khanna \& Palepu, 2013; Ramamurti, 2012). For its part, the African context shapes managerial choices because of limited access to capital and human resources, managerial and technological capability, and respect and legitimacy (Barnard, 2014; Barnard et al., 2017; George, Corbishley, Khayesi, Haas, \& Tihanyi, 2016). In particular, persistently weak institutions, political volatility, linguistic and ethnic diversity, vast diasporas, questions about African firm legitimacy, and the recent colonial legacy all conspire to test the applicability of existing international business theory (Barnard et al., 2017: 482-484). The goal of this paper is to explore how the African context, and especially the colonial legacy, shape the internationalization process.

In the next section, we introduce our study setting and sketch the effects of colonialism on the institutions, migration patterns, education, and the like in Francophone African countries. We then dive into the literatures on internationalization trajectories (Johanson \& Vahlne, 2009; Luo \& Tung, 2018; Mudambi, 2008) and legitimacy (Kostova, Roth, \& Dacin, 2008; Scherer, Palazzo, \& Seidl, 2013) to articulate questions about how experience in the frontier economies of Africa shape internationalization processes. Subsequently, we describe our method and introduce six illustrative cases. We then compare the experience of these firms to theory, leading to the idea of l'effet métropolitain, that is, a legitimacy-building internationalization trajectory that follows network ties through the colonial center and out into the wider world. We conclude the paper by developing a research agenda for exploring the dimensions and testing the prevalence of the metropolitan effect.

(C) 2019 The International Association for Chinese Management Research 


\section{THE EFFEGT OF THE GOLONIAL LEGACY ON FRANCOPHONE AFRICAN FIRMS}

We chose to study the internationalization experience of Francophone African firms because they operate in challenging frontier and emerging economies (Mody, 2004; S\&P Global, 2017) that, together, comprise a population of almost 350 million (Table 1) and, as such, provide an interesting, non-trivial context in which to challenge the conceptual reach of extant theory.

In Africa, colonialism arrived relatively late, lasted into the more recent past, and had particularly strong effects as compared to other regions of the globe (Gann \& Duignan, 1967). Colonial rule was typically implemented by transplanting the institutions of the metropolitan center into the conquered country (Dia, 1996), and this was certainly true in Francophone Africa (Lee \& Schultz, 2012). Here, we use the term 'metropolitan' in its more general meaning as 'relating to, or constituting a mother country as distinguished from a colony' (Merriam-Webster, 2018). Thus, the French Empire was composed of the metropolitan center (France) and its colonies scattered all around the globe.

French colonial rule was 'erected on an ethnocentric assimilationist paradigm that refused to interpret culture as a dynamic process and, accordingly, to incorporate African cultural elements, preferring instead to dismiss, repudiate and systematically erase African identity' (Thomas, 2007: 9). The goal was total assimilation of the colonized population through the creation of institutions (educational, administrative, legal, etc.) and systems (financial, infrastructures, etc.) that mirrored those in the home country. French institutions were recreated in African colonies through a specially trained cadre of local employees who were imbued with French culture and values (Osborn, 2003).

The institutional effects of colonialism have persisted. The transplanted institutions included significant elements of government and business systems as well as of physical infrastructure systems like roadways, railways, power systems, building codes, and the like. To this day, airline networks from Francophone African cities, including capital cities, are overwhelmingly linked to the world through the Paris hub (Zook \& Brunn, 2005). In Francophone Africa, countries in Western and Central Africa were incorporated into CFA franc zones (in which local francs were guaranteed by the France) that remained in force for decades after formal independence (Stasavage, 1997). This international financial system provided one mechanism through which colonial ties continued to shape international business operations (Mudambi, 1998). Further, the administrative, legal, educational, and physical infrastructures of the postcolonial countries still mirror metropolitan France with a capital as the hub. Finally, the original cadre of employees trained to aid the French rulers have grown into a Francophone upper class that is still often educated in France and is comfortable moving back and forth from their home countries to France (Ekeh, 1975).

Studies have shown that historical ties, including colonial ties, create a context that continues to shape MNE activity including trade patterns and FDI (Lundan \& 
Table 1. Francophone countries in Africa

\begin{tabular}{llr}
\hline \hline & \multicolumn{1}{c}{ Country } \\
No. & Population $(2010)[1][2]$ \\
\hline 1 & Dem. Rep. of the Congo & $67,827,000$ \\
2 & Mlgeria & $37,900,000$ \\
3 & Morocco & $33,848,242$ \\
4 & Madagascar & $21,146,551$ \\
5 & Cameroon & $19,958,692$ \\
6 & Ivory Coast & $21,571,060$ \\
7 & Burkina Faso & $16,287,000$ \\
8 & Niger & $15,891,000$ \\
9 & Senegal & $12,861,259$ \\
10 & Mali & $14,517,029$ \\
11 & Tunisia & $10,982,754$ \\
12 & Rwanda & $10,277,282$ \\
13 & Chad & $10,329,208$ \\
14 & Guinea & $10,324,437$ \\
15 & Burundi & $8,519,005$ \\
16 & Benin & $9,212,000$ \\
17 & Togo & $6,780,000$ \\
18 & Central African Republic & $4,410,873$ \\
19 & Republic of the Congo & $4,043,318$ \\
20 & Mauritania & $3,537,368$ \\
21 & Gabon & $1,501,000$ \\
22 & Comoros & 734,75 \\
23 & Equatorial Guinea & 700,401 \\
24 & Djibouti & 888,716 \\
25 & Seychelles & 86,525 \\
Total & Francophone Africa & $344,135,470$ \\
\hline \hline
\end{tabular}

Notes: [1] World Atlas, 2012.

[2] World Development Indicators, 2012. World Bank, Washington DC

Jones, 2001; Makino \& Tsang, 2011; Rangan \& Drummond, 2004). This colonial legacy serves as both a context of and starting point for our exploration of the internationalization trajectories of Francophone African firms. Further, in many ways the French colonial empire is representative of colonialism more generally, so that our analysis of these firms may have broader implications for firms from other former colonies.

Thus, in keeping with the notion that African experience may challenge theory developed in other contexts (George, 2015), we ask: What does the experience of Francophone African firms tell us about how the colonial legacy affects the internationalization trajectories of such firms?

\section{Internationalization Trajectories and Legitimacy}

In this exploratory paper, we focus on the process of internationalization. The internationalization process is initiated by a variety of factors. Dunning (1993) identified three primary factors - market-seeking, asset-seeking, and resource-seeking - as well as a number of secondary drivers, such as escape. Over the years, scholars 
have recast these as market reach, search, exploit, and escape (Cuerva-Cazurra, Narula, \& Un, 2015). Market reach refers to the quest for additional customers (Buckley, Clegg, Cross, Liu, Voss, \& Zheng, 2007; Moghaddam, Sethi, Weber, \& $\mathrm{Wu}, 2014)$. Search encompasses efforts to acquire access to crucial technologies, resources, and competencies that are not available in firms' domestic environments (Awate, Larsen, \& Mudambi, 2012). Exploit involves leveraging cost efficiencies to carry out low-knowledge, standardized activities with the explicit goal of acquiring the capabilities, connections, and resources to become global competitors (Kothari, Kotabe, \& Murphy, 2013; Mudambi, 2008; Witt et al., 2018). Finally, escape describes flight from the uncertainty arising from weak institutions, poor or non-existent infrastructure, non-functional labor markets, and especially unpredictable, conflict-filled relationships with government (Barnard \& Luiz, 2018; Buckley et al., 2007; Cuervo-Cazurra \& Genc, 2011).

Given the exigencies of doing business in a frontier economy, we would expect escape to play a large part in driving Francophone African firms to internationalize. Less clear is whether these same conditions might affect the internationalization processes chosen by these firms.

Internationalization trajectories. While there have been many attempts to articulate trajectories of internationalization, Johanson \& Vahlne's internationalization process (Johanson \& Vahlne, 1977, 2009), internationalization that follows MNE value chains, and Luo \& Tung's springboard model (Luo \& Tung, 2018) stand out as particularly relevant to our study of the internationalization trajectories of Francophone Africa firms.

In their well-known process theory of internationalization, Johanson and Vahlne drew on the experience of Swedish firms to develop a learning model in which firms cross relatively short institutional, cultural, and geographic distances; gradually increase commitments as they learn to operate effectively in new contexts; and then use their new platform, experience, and resources to move onto the next market (Johanson \& Vahlne, 1977, 2009). As the model has evolved, the roles of networks and relationships and 'insidership' have become more prominent than simple geography, and the challenges of institutional distance and 'outsidership' that is, of not being used to a country's rules or belonging to a country's business networks - more pronounced than culture per se (Cantwell \& Mudambi, 2011). Still, the predicted internationalization trajectory is of gradually increasing scale, scope, and commitment, starting with host countries that are somehow proximate to the home country. Following the logic of this model, one might expect Francophone African firms to follow the language and institutional gradients defined by colonialism to internationalize first into neighboring Francophone countries.

A second well-known internationalization trajectory involves firm participation in the global value chains dominated by developed country MNEs. Firms join MNE value chains by offering similar quality at reduced cost, but as new arrivals in mature industries, firms may find or create innovations that enhance their ability to compete 
effectively with advanced economy companies tied to legacy equipment and practices (Awate, Larsen, \& Mudambi, 2012; Lewin, Massini, \& Peeters, 2009; Ramamurti, 2012). In any case, by participating in an MNE's global value chain, emerging market firms can find ways to overcome the institutional, cultural, and business systems distances between their emerging, home market and target, host, markets (Beugelsdijk \& Mudambi, 2013; Kumaraswamy et al., 2012; Peng, Wang, \& Jiang, 2008; Schotter, Mudambi, Doz, \& Gaur, 2017).

Opportunities to internationalize through participation in global value chains are highly correlated with financial connectivity between countries. For instance, the enormous FDI into China has been linked to the internationalization of Chinese firms (Boisot \& Meyer, 2008). The challenge for many African firms outside of South Africa is that without substantial MNE investment in a country, opportunities for local firms to leverage MNE value chains are few. While trade with and FDI in Africa is growing, it is still quite limited, and much of the FDI that is recorded is Chinese FDI in search of access to natural resources and served almost entirely by Chinese suppliers of services and labor, rather than local ones (Buckley et al., 2007; Shinn \& Eisenman, 2012). ${ }^{[1]}$ This lack of connectivity leaves many African firms struggling to develop the capabilities, market knowledge, legitimacy, and opportunity required to participate effectively in global value chains (Stevens \& Newenham-Kahindi, 2017; Wang \& Cuervo-Cazurra, 2017). ${ }^{[2]}$

Luo and Tung (2018) articulate a third internationalization trajectory in which well-endowed emerging market MNEs explode onto the global stage by aggressively and strategically acquiring critical assets from mature MNEs until they have assembled enough of a portfolio to compete with, or even surpass, their established competitors. This risky approach requires both long-term thinking and deep pockets, often facilitated by market and/or political support at home, as has often been the case for Chinese firms (Luo \& Tung, 2018). But the springboard trajectory of internationalization is limited to the most well-funded, sophisticated frontier and emerging market firms and does not adequately address the evolution of (smaller) MNEs or the 'soft power deficits of many emerging market economies' that can harm the legitimacy of even the most sophisticated frontier or emerging market firm (Luo \& Tung, 2018: 134).

Legitimacy. Whatever their internationalization trajectory, firms from frontier economies in general, and perhaps from Africa in particular, struggle to earn the legitimacy necessary to bridge institutional and cultural distances and operate effectively in host countries, especially in emerging and developed markets (Barnard, 2014). We understand legitimacy as the 'generalized perception or assumption that the actions of an entity are desirable, proper, or appropriate within some socially constructed system of norms, values, beliefs, and definitions' (Suchman, 1995: 574). Legitimacy has been shown to be required for firms to receive a socially sanctioned 'license' to operate in a new country (Bitektine, 2011; Claasen \& Roloff, 2012; Scherer, Palazzo, \& Seidl, 2013). Especially 
when firms suffer 'liabilities of origin' through association with a frontier or emerging economy's suspect institutional environment (Pant \& Ramachandran, 2012: 226), legitimacy must be continually earned and reaffirmed in an ongoing dialog between firms, stakeholders, and social actors (Suddaby \& Greenwood, 2005) for example through investments in better products or services; lobbying; publicity; attempts to mobilize sociopolitical actors; and measurement and validation efforts (Darendeli \& Hill, 2016; Henisz, Dorobantu, \& Nartey, 2014; Pant \& Ramachandran, 2012). Effective internationalization requires effective intentional and sophisticated efforts to span boundaries and build legitimacy in host countries (Kostova et al., 2008; Schotter et al., 2017), leading to our second question: What does the experience of Francophone African firms tell us about how such firms overcome the legacy of colonialism to build the legitimacy necessary for the internationalization process to be effective?

\section{METHOD: EXPLORATORY GASE STUDIES OF THE INTERNATIONALIZATION OF FRANCOPHONE AFRICAN FIRMS}

To build theory about how Francophone African firms internationalize, given the constraints of their origins in the frontier economies of Francophone Africa, we employ an exploratory, theory-building case study approach (Eisenhardt \& Graebner, 2007; Yin, 2002). Specifically, we describe and compare to theory the internationalization experience of six francophone African firms. To increase confidence that any pattern articulated reflects general conditions, not idiosyncratic ones, we purposely chose firms that were small and large, new and old, and anchored in different countries and industries. Because our goal was to induce new dimensions of internationalization theory from phenomena, we focused simply on the internationalization trajectory of each firm; the testing of the validity of the patterns identified awaits further research.

Data were collected through interviews with firm principals, supported by secondary documents. The interviews were conducted in French and promptly translated into English to facilitate discussion among the authors of themes and patterns seen in the data. As we explored the data, we attempted to organize it into tables and diagrams that expressed critical relationships. Such attempts at organization and visualization led to useful insights, including, for example, the idea of relationship upgrading as a mechanism for developing legitimacy. Finally, as we prepared this paper, we moved back and forth between theory, categories, visualizations, and the original data until we were able to articulate a series of insights that were at once consistent with the experience on the ground and useful for refining theory (Birkinshaw, Brannen, \& Tung, 2011; Eisenhardt \& Graebner, 2007).

\section{Six Internationalization Stories from Francophone Africa}

In the following section, we tell the internationalization stories of Outsourcia from Morocco; Favizone, Misfat Filtration, and Valomnia from Tunisia; Talent2Africa 
from Senegal; and BGFI Bank from Gabon. Combined, their experience suggests that Francophone African firms follow an internationalization trajectory in which firms follow network and historical ties to France to garner the resources, capabilities, and legitimacy necessary to move farther afield, including back to neighboring African countries.

Outsourcia is a relatively large, fast-growing business process outsourcing (BPO) and information technology outsourcing (ITO) provider that was established in Morocco in 2003 when the Moroccan principals bought out an international partner in a start-up call center. The company specialized in the management of the remote customer relationship and became a multi-service, multilingual, and multi-channel business (call centers, email management, chat solutions, telemarketing, and customer relationships on social networks). In 2004, Outsourcia had only 70 employees and a turnover of $€ 0.6$ million. Through a mixture of acquisition of domestic firms and organic growth, Outsourcia increased its revenues to $€ 2.1$ million in 2006, €4.1 million in 2008, and $€ 19$ million by 2010. In early 2010, Outsourica entered France by acquiring the French call center operator As-com. The acquired firm had sales of $€ 3.6$ million and had been in business since 1988. This was the first such international expansion by a Moroccan firm. Commentators in the French business press noted that Outsourcia was following the model of Indian and Chinese firms that entered Europe through acquisition to obtain knowledge assets (e.g., Awate et al., 2012).

To go to France...was natural, because the similarities are cultural, language, how to deal with business... and it was necessary, because I wanted to be aware of what is done in this sector in France and because we were dealing directly with customers in France.

In October 2011, Outsourcia opened its own bespoke office in Evreux in Normandy, in search of more stable institutional settings, improved technologies, increased capabilities, and increased sales. Also, in 2011, the firm acquired Alias Community, a digital enterprise focused on social media, anticipating a major industry trend: the customer relationship management on social networks. The firm's continued growth required it to open a second location by rehabilitating a site in Châtillon-en-Dunois in 2014.

Going to France, it is not for the capital because that can be obtained in Morocco. We went to France because I was already addressing the French market. The market issue is one of the reasons; the second reason is the credibility and legitimacy. The fact of going there made it possible to settle in a much more durable way in France.

Outsourcia grew at a sustained rate of 15\% per annum, developing important French clients, such as Peugeot Citroen, Coface, Brand Alley, and Seloger, as well as global suppliers such as Avaya and Vocalcom. Outsourcia also made use 
of several prominent French business services, including Société Générale for banking and Mazars and Darrois Villey for accounting and legal services.

By 2015, Outsourcia's French operations had established it as a successful multinational player in the industry and were generating substantial financial resources. The firm leveraged the improved reputation and financial assets that it developed in France to enter locations in Africa, starting with Cameroon and Senegal, followed by Niger in 2015 and later by entering Madagascar with the acquisition of a majority stake in SCEMI SA, a company specializing in outsourcing services offshore that employed 650 staff.

We are in Morocco because we started in Morocco. It was imperative for us to go to France because of customers; if we want to address the Francophone market, it is mandatory. Third, we are in sub-Saharan Africa because we wanted access to new employment areas... and because we manage to produce 30-35\% cheaper than in Morocco. So, today for my clients, I have onshore offer in France, half-offshore in Morocco and offshore in subSaharan Africa and soon in Mauritius or Madagascar.

Misfat Filtration is a very well-established manufacturer that started its activities in Tunisia in 1979. After many years in the auto part distribution business, during which the company learned the needs of the auto part distributors it served, Misfat developed a manufacturing arm focused on motor vehicle filters (oil, fuel/diesel, air and cabin air filters) for light, commercial, and heavy-duty vehicles. After 30 years in business, Misfat became the leader within the Tunisian market and commenced a process of internationalization.

Misfat moved first to France (Crépy-en-Valois, Picardy) in 2009 by acquiring a well-known French company, Solaufil France, with its Mecafilter and Laurette brand, and its Spanish affiliate, Solaufil Iberica. The combination of Solaufil's business image, know-how, and relationships with French business services, such as the banks Credit Lyonnais and Société Générale and the accountancies Cecaudit International and Demon provided near instant legitimacy to Misfat in France and indeed, throughout Europe; these relationships also increased Misfat's access to capital dramatically.

Misfat quickly leveraged its newfound resources and legitimacy by building a manufacturing site and regional distribution center in Casablanca, Morocco in 2010. Since that time, Misfat has continued its rapid growth and international expansion by first opening a new subsidiary in Poland, and then inaugurating a regional distribution site based in Moscow in 2014. Within only seven years of its initial internationalization into France, Misfat has become a successful African multinational firm recognized for high-quality products and with well-known customers all over the world.

According to Amin ben Ayed, General Director of the Misfat Group,

This is the story of a Tunisian firm which was struggling to internationalize and managed to do so via the acquisition of a French firm. This is also the story of a 
French firm which could no longer thrive in a competitive international environment and adopted a competitive cost structure by collaborating with a Tunisian company. The result was the creation of wealth and employment on both shores of the Mediterranean' (Ipemed, 2016).

Smaller firms - Favizone \& Valomnia. Favizone launched in Tunis in 2014 to create an ecommerce platform for merchants and in early 2017 opened a subsidiary in France

for the commercial part....to begin testing the business process, pricing, commercial pre-testing of various distribution channels, and so on. We chose France because we were looking for a market, because the Tunisian market could not absorb the services of Favizone... [and] because the biggest challenge of a start-up is the first sale, the first marketing, so linguistic and cultural proximity helps a lot. I do not see any difference between a Tunisian or a French client, [but] if I have to manage an English client, I will be able but not have the same ease.

There were personal reasons as well. 'I studied in Paris, I lived there for seven years. I have a good personal address book that I wish to exploit to succeed in the start-up. So France and Paris imposed themselves automatically; I did not even try to look elsewhere'. And finally, hopes for capital: '...the idea is to do the pre-test in France, validate the business plan assumptions, and get up funds to attack Europe and the rest of the world'.

Valomnia, a software firm with a sales-representative-tracking application, is somewhat more established, having started in 2012 and set up a subsidiary in France in 2016.

Why choose France? The relations between Tunisia and France are very close. I myself spent 11 years in France, studying and work, so I know very well the French ecosystem and have a good network. It was the cultural rapprochement that prompted me to go to France. That is the first point. The second point is that France is currently structuring the digital economy,... and there are many advantages especially in terms of $\mathrm{R} \& \mathrm{D}$ and, the most important for us, in raising funds.

Having gone to France, Valomnia has no plans to start subsidiaries in other Francophone countries in Africa; rather, they plan to use their platform in France to sell through partners:

If it were up to us, we would have stayed in Tunisia, but France represented an opening for us....the goal is not to go everywhere. We are in the digital sector, so we do not need local structures. It's enough to work with local partners. Our objective through the French subsidiary is to increase visibility...

BGFI Bank is the leading banking group of the central African economic and monetary community (Central African CFA franc zone). This Gabonese bank 
started its activities in Libreville in 1971, operating under the name of Bank of Paris and the Netherlands Gabon.

Twenty-five years later and as part of the bank efforts to expand its international operations, the bank rebranded itself as BGFI an acronym for its former name of 'Banque Gabonaise et Française Internationale', and started an aggressive internationalization expansion in Africa by moving first into Congo in 2000 and Equatorial Guinea in 2001. This expansion did not produce the hoped-for results, and the bank retreated. In time, it applied for and obtained in 2009, the approval of the Credit Institutions and Investment Firms Committee (CECEI) to operate in France as a financial company for the benefit of corporate clients. The choice to temporarily abandon the African adventure and to locate in France instead served a dual purpose. One purpose was to gain the legitimacy as trustworthy partner, and the second was to offer international investors direct access to investment opportunities in Africa and to serve African firms from France by providing them with greater access to international capital markets.

Only one year after opening its business in France, BGFI bank was able to leverage its status as a French bank and its access to capital to enter Francophone countries, such as Cameron, Benin, Congo, and Senegal, that are more geographically proximate to the home country of Gabon. BGFI continued to expand and is now more diversified and more global with presence in 11 countries (France and ten African countries).

Talent2Africa started in Senegal in 2015 to facilitate the hiring of qualified African employees for MNEs doing business throughout Francophone Africa. 'In Africa, we have a multitude of small countries, in terms of size from an economic point of view, so...we decided to intervene on a wider radius, in geographic terms, and [target] all Francophone Africa, including the Maghreb and in particular Morocco'.

But to do this, Talent2Africa went first to France because 'most of the multinationals on the African continent belong to groups based in Europe, in Paris in particular. So this is where the decision to move closer to France was born because our customers are there... and because France is the gateway to all of Francophone Africa'. Of course, access to capital was also a draw and a shared language and having lived in Paris made it easier. Finally, there was 'the [francophone] diaspora, which is our core target. In Europe, we think of Paris where we have more than two million members of the diaspora. If we were talking about Nigeria, Ghana, Kenya, we would have gone to England...'. Indeed, 'our main resources are a mixture of knowledge of and experience in the [target industries] and the relationships that we have in the African diaspora in France'.

\section{INTERNATIONALIZATION PROGESS INSIGHTS FROM FRANCOPHONE FIRMS}

The six firms interviewed all followed a similar trajectory: Internationalizing first to France, largely in search of markets, knowledge, and legitimacy. This pattern is 
partly consistent with existing theory, but also suggests two new insights: First, that the colonial metropole continues to exert a strong pull on frontier economy firms and, second, that part of the attraction is the opportunity to build the legitimacy necessary to overcome the 'soft power deficits of many emerging market economies' (Luo \& Tung, 2018: 134) by becoming successful in a developed market. The experience of the firms studied also highlights the role of networks, especially social networks, in the actual process of internationalization.

\section{All Roads Still Lead through Paris: Francophone African Firm Internationalization Trajectories}

Reading the accounts and studying the internationalization trajectories summarized in Table 2, it is striking that, with the exception of BGFI, each of the firms chose to internationalize to France first. Even BGFI, which first tried to expand into geographic and cultural neighbors, found success only when it retreated from Africa, entered and rebranded in France, and then re-entered Africa.

The firms studied gave many reasons for going to France, notably expanded market reach and search for capital, technology, and legitimacy. ${ }^{[3]}$ Outsourcia employed a springboard strategy (Luo \& Tung, 2018), buying a French firm with access to markets and legitimacy (e.g., reference customers), and then expanding elsewhere in Francophone Africa to exploit labor cost advantages. Misfat leveraged its experience in global value chains to upgrade steadily, and then internationalized by buying a French company with access to markets and legitimacy (in this case, well-known brands and highly respected bank and accounting partners), while continuing to exploit its cost advantages in Tunisia. Favizone and Valomnia chose France for access to markets and technology, while BGFI used France to bolster its legitimacy as a credible corporate partner and to establish itself as a conduit for capital flows in both directions between Africa and Europe. Finally, Talent2Africa chose France for its concentration of capital, customers with global reach, and diasporan labor pool, with its combination of language, cultural know-how, and low-cost.

In all cases, the firms studied could have chosen markets that shared a language and were geographically and culturally closer than France, and yet the firms studied still chose France. This choice challenges the classic Johanson and Vahlne model of internationalization process with its emphasis on geographic and cultural proximity, but is more consistent with their 2009 reformulation in which they emphasize the importance of networks and insidership in relevant network(s)' when bridging geographic, institutional, and cultural distances (Johanson \& Vahlne, 2009: 1411). Indeed, while the firms studied cited customers, knowledge, and capital as reasons to go to France, several also added the important detail that their path into the business networks was built on foundations of familiarity and personal networks built during university days in France and/or through their social network within the diaspora; clearly, the individual manager and her

(C) 2019 The International Association for Chinese Management Research 
Table 2. Internationalization trajectories

\begin{tabular}{|c|c|c|c|c|}
\hline Company & Home Country & Move 1 & Move 2 & Move 3 \\
\hline Outsourcia & Morocco & France $(2010)$ & $\begin{array}{l}\text { Cameroon \& } \\
\text { Senegal }\end{array}$ & Niger (2015) \\
\hline Misfat & Tunisia & France (2009) & Morocco (2010) & $\begin{array}{l}\text { Poland \& Russia } \\
\text { (2014) }\end{array}$ \\
\hline Favizone & Tunisia & France (2017) & Pending & \\
\hline Valomnia & Tunisia & France (2016) & Global (online) & \\
\hline BGFI (as a State bank) & Gabon & Congo (2000) & $\begin{array}{l}\text { Equatorial Guinea } \\
(2001)\end{array}$ & $\begin{array}{l}\text { Retreat from } \\
\text { both Congo \& } \\
\text { Guinea }\end{array}$ \\
\hline $\begin{array}{l}\text { BGFI Reset } \\
\text { (after near-failure) }\end{array}$ & Gabon & France (2009) & $\begin{array}{l}\text { Rapid expansion to } \\
\text { Cameroon, Benin, } \\
\text { Congo, Senegal... } \\
\text { (starting 2010) }\end{array}$ & \\
\hline Talent2Africa & Senegal & France & $\begin{array}{l}\text { Digital expansion to } \\
\text { Francophone Africa }\end{array}$ & \\
\hline
\end{tabular}

social networks are critical to theorizing about internationalization (CuervoCazzuro et al., 2015).

In nearly all cases, there was an explicit recognition that France was special (see Table 3). The firms interviewed chose France for their first foray abroad because it offered so much in one place: France was linguistically and culturally and personally familiar; it was the bridge to the developed world's customers, technology, and capital; it was a one-stop shop for access to companies serving, and people from, all of the Francophone countries of Africa; and success in France conferred legitimacy as a firm capable of operating in developed economies. In short, more than a half a century after the end of colonialism, the old colonial center still promises - and delivers - the world to firms from Africa. This is l'effet métropolitain and is an important addition to the trajectory and motivations of internationalization for firms from countries shaped by colonialism.

The critical role of legitimacy. For most of the companies interviewed, there was the expectation, often realized, that success in France would confer a certain legitimacy that, in turn, would open doors for increased sales, additional resources, and entry into other countries (see Table 4). That is, the managers interviewed quite consciously pursued internationalization to France to prove their ability to compete in developed markets and so signal readiness and ability to compete anywhere. Such legitimacy was gained through sheer presence in France (Valomnia), the ownership of French brands (Misfat), ties with highly credible government and corporate partners (BGFI, Misfat, Talent2Africa), and proven success selling within the sophisticated and global French market (all firms studied). In short, to overcome the 'liabilities of origin' (Pant \& Ramachandran, 2012) associated with originating from a frontier or emerging economy, the firms studied sought out legitimacy by expanding to France first, before internationalizing elsewhere. The 
Table 3. The enduring colonial legacy: France is still the center of the Francophone World

\begin{tabular}{|c|c|}
\hline Company & Why France? \\
\hline Outsourcia & $\begin{array}{l}\text { 'To go to France...was natural, because the similarities are cultural, language, } \\
\text { how to deal with business...'. } \\
\text { 'To go to France... was necessary because I wanted to be aware of what was } \\
\text { done in this sector in France and because we were dealing directly with cus- } \\
\text { tomers in France'. } \\
\text { 'It was imperative for us to go to France... if we want to address the } \\
\text { Francophone market, it is mandatory'. }\end{array}$ \\
\hline Misfat & no evidence \\
\hline Favizone & $\begin{array}{l}\text { '[T] he biggest challenge of a start-up is the first sale, the first marketing, so the } \\
\text { linguistic and cultural proximity helps a lot. I do not see any difference between } \\
\text { a Tunisian or a French client, [but] if I have to manage an English client, I will } \\
\text { be able but not have the same ease'. } \\
\text { 'I studied in Paris, I lived there for seven years. I have a good personal address } \\
\text { book... [s]o France and Paris imposed themselves automatically; I did not even } \\
\text { try to look elsewhere'. }\end{array}$ \\
\hline Valomnia & $\begin{array}{l}\text { 'It was the cultural rapprochement that prompted me to go to France. That is } \\
\text { the first point'. } \\
\text { 'I myself spent } 11 \text { years in France, studying and work, so I know very well the } \\
\text { French ecosystem and have a good network'. }\end{array}$ \\
\hline $\begin{array}{l}\text { BGFI Reset } \\
\text { (after near- } \\
\text { failure) }\end{array}$ & $\begin{array}{l}\text { Becoming chartered in France established BGFI as a bridge between inter- } \\
\text { national investors and African investments, and African firms and French } \\
\text { investment vehicles. }\end{array}$ \\
\hline Talent2Africa & $\begin{array}{l}\text { ' }[\mathrm{M}] \text { ost of the multinationals on the African continent belong to groups based in } \\
\text { Europe, in Paris in particular'. } \\
\text { 'So this is where the decision to move closer to France was born because our } \\
\text { customers are there ... [and] France is the gateway to all of Francophone } \\
\text { Africa'. } \\
\text { 'In Europe, we think of Paris where we have more than two million members of } \\
\text { the diaspora. If we were talking about Nigeria, Ghana, Kenya, we would have } \\
\text { gone to England...'. }\end{array}$ \\
\hline
\end{tabular}

irony is, of course, that as a colonizer, France played a decisive role in stunting the economic and institutional development of Francophone Africa. And yet, the metropole still exerts its centripetal force, pulling Francophone African firms back to France, in large part to prove their ability to flourish in a global, developed context - and so gain the legitimacy required to expand into other countries.

\section{THE METROPOLITAN EFFEGT: TOWARDS A PROGESS MODEL OF INTERNATIONALIZATION OF FIRMS IN POSTGOLONIAL FRONTIER ECONOMIES}

This is an exploratory, conceptual paper based on the internationalization experience of six firms from Francophone Africa. Our study takes advantage of the extreme conditions common to the frontier economies of Africa and of newly observed phenomena such as the overwhelming preference for France as the first step in internationalizing to test and extend existing theory (George, 2015; Barnard et al., 
Table 4. France as the source of legitimacy

\begin{tabular}{|c|c|}
\hline Company & To France for Legitimacy? \\
\hline Outsourcia & $\begin{array}{l}\text { 'Going to France, it is not for capital... [t] he market issue is one of the reasons; } \\
\text { the second reason is credibility and legitimacy'. }\end{array}$ \\
\hline Misfat & $\begin{array}{l}\text { Misfat internationalized by buying Solaufil France, an established French firm } \\
\text { with two well-known brands and long-time relationships with well-regarded } \\
\text { banks and accounting firms. } \\
\text { 'This is the story of a Tunisian firm which was struggling to internationalize } \\
\text { and managed to do so via the acquisition of a French firm'. }\end{array}$ \\
\hline Favizone & no evidence \\
\hline Valomnia & $\begin{array}{l}\text { 'We are in the digital sector, so we do not need local [country] structures. It's } \\
\text { enough to work with local partners. Our objective through the French sub- } \\
\text { sidiary is to increase visibility...' }\end{array}$ \\
\hline $\begin{array}{l}\text { BGFI Reset } \\
\text { (after near-failure) }\end{array}$ & $\begin{array}{l}\text { Sought the approval of the Credit Institutions and Investment Firms } \\
\text { Committee to operate in France - explicitly to gain legitimacy as a trust- } \\
\text { worthy corporate partner. }\end{array}$ \\
\hline Talent2Africa & $\begin{array}{l}\text { Sought relationships with the multinationals based in France - to be able to } \\
\text { reach all of Francophone Africa. }\end{array}$ \\
\hline
\end{tabular}

2017). Our results are largely consistent with existing theories of internationalization trajectories and motivations (Buckley, 2018), but add important dimensions to them.

In other words, l'effet metropolitain can co-exist with or form the basis for other trajectories. In the colonial context, it reflects the underlying logic of the trajectory. Thus, while l'effet metropolitain ensures the central role of France, the internationalization process can take different forms, e.g., Outsourcia is a case of springboarding, while Misfat an example of GVC-driven internationalization. However, in the all the cases, the colonial metropole offers an extremely attractive first step in internationalization for firms from post-colonial frontier economies. The search for legitimacy is a critical addition to the upgrade motivation for internationalizing (CuervoCazzura et al., 2015). Further, in making the move to the colonial center, social networks seem to complement business networks in increasing 'insidership' by spanning cultural, geographical, and institutional gaps (Cantwell \& Mudambi, 2011; Johanson \& Vahlne, 2009).

Drawn as they are from an exploratory study, each of these insights warrants further theoretical elaboration and empirical testing.

\section{The Colonial Metropole Offers and Extremely Attractive First Step in Internationalization for Firms from Post-Colonial Frontier Economies}

The firms interviewed all chose to internationalize first to France because it offered markets, capital, knowledge, legitimacy, all in a familiar setting. Old colonial ties, including shared language, shared institutions, shared culture, direct transportation links, diasporas, cross-border multinationals and more, seem to provide a direct connection from frontier and emerging to developed markets. While there 
exists some evidence that firms in former colonies trade more than expected with the colonial metropole (Makino \& Tsang, 2011), there is a need for more specific research into the role of colonial ties in shaping internationalization trajectories, and into the mechanisms - whether hard such as transportation links or soft such as culture or social networks - that influence the interplay between firms from former colonies and the colonizing country.

Looking beyond the first step of internationalization, it might be productive to explore whether and how the colonial legacy affects subsequent steps. For example, none of the firms interviewed talked explicitly about joining global value chains, although Misfat Filtration clearly built upon their experience in the automotive value chain and BGFI specifically sought to join the global finance network before relaunching into Africa. But even if they learned from participation in global value chains, neither Misfat nor BGFI followed the chain around the developed world: Rather, both went to France and then to Africa, and in Misfat's case, on to Poland and Russia. Their trajectories, along with those of Outsourcia and Talent2Africa (to France and then to Africa), suggest the possibility of a 'boomerang' effect, such that firms internationalize first to the colonial center and then follow social, linguistic, and institutional gradients back to countries that were themselves colonies under the same regime, rather than following more conventional value chain-based or proximity-based trajectories.

\section{Gaining Legitimacy is a Critical Component of Upgrading Capabilities during the Internationalization Process}

The search for legitimacy, and the credible signaling of legitimacy based on a claim to a 'second home' in an advanced economy, seem to be both important, and as yet underappreciated, steps in the internationalization process. Such legitimacy is important because a firm's ability to earn and maintain legitimacy and so a 'license to stay' (Boddewyn, 1995) has been shown to be a threshold condition for firm success in a host country and also a source of credibility as the firm strives to enter new countries (Kostova et al., 2008). There is ample opportunity to explore how firms from frontier and emerging markets might best earn legitimacy, for example, through active advocacy (Pant \& Ramachandran, 2012) or conscious choice of legitimacy-generating products and services (Darendeli \& Hill, 2016), and also signal legitimacy, for example, by association with credible countries or customers. And of course, it is important to test whether earned and signaled legitimacy actually increase the speed and/or success of internationalization efforts.

\section{Social Networks Seem to Complement Business Networks in Guiding Internationalization Trajectories}

The firms in our study chose France as the first place to internationalize in part because the shared language and colonial heritage ensured that the former colonial 
center felt remarkably familiar - as reflected in the old adage that 'Morocco is a tree with roots in Africa and its trunk and branches in Europe'. That is, the perception of commonalities often proves more important than more objective measures of distance or of border effects (Beugelsdijk \& Mudambi, 2013; Williams \& Grégoire, 2013), and many of the respondents commented specifically on the influence of familiarity and social networks developed during university in making the choice to internationalize to France. This insight complements recent emphasis on the role of business networks in enabling internationalization (Vahlne \& Johanson, 2017) and, as in the Talent2Africa interview, highlights the role of the Francophone African diaspora in facilitating business in France. In both emerging and frontier economies, culturally competent, boundary-spanning individuals play an essential, entrepreneurial role in making internationalization happen (Sarasvathy et al., 2014) by crossing institutional and cultural distances, searching out opportunities and resources, building relationships in new countries, and facilitating learning (Saxenian, 2005, 2007; Vahlne \& Johanson, 2017).

Such individuals have been shown to embody flows of capabilities, knowledge, and resources that enable internationalization (Kuznetsov, 2006; Schotter \& Abdelzaher, 2013; Schotter et al., 2017), while providing the insider connections into an economy and society that are necessary for building inroads into new markets (Riddle, Hrivnak, \& Nielsen, 2010). As promising as the role of diasporas in internationalization may be (Kuznetsov, 2006), actually connecting the business and social networks of African and developed countries can be quite challenging, even for boundary-spanning individuals (Mayer, Harima, \& Freiling, 2015), whose willingness and ability to connect depends on their feelings for their countries of origin and residence (Barnard \& Pendock, 2013); business and knowledge types and strength of specific interpersonal ties (Levin \& Barnard, 2013); and serendipity (Lorenzen \& Mudambi, 2013).

There is opportunity to combine the research on the role of diasporas in internationalization with the details about the role of the Francophone African diaspora in facilitating flows of information and resources both to explain the lingering lure of the colonial metropole and to develop a more robust understanding of networks and insidership in internationalization. Further, it is also possible that diasporas may serve to create hierarchical links that act in a very similar manner to colonial links. For instance, the hierarchical knowledge connectivity between the Indian diaspora in Silicon Valley and the home country (India) may operate in a manner similar to that between the various African diasporas in France and their respective (former colonial) home countries.

\section{Towards a Process Model of Internationalization of Firms from Postcolonial Frontier Economies}

Although much research remains to be done into each of the insights suggested in this paper, the combination of insights suggest a nascent process model of 
postcolonial internationalization consisting of three steps: 1) The development of resources and competitive advantage in the home country; 2) internationalization to the colonial metropole to expand markets, assemble resources, develop capabilities, and especially build legitimacy; and 3) further expansion, often back into Africa to neighboring countries, enroute to becoming a global competitor.

We argue that the experience of Francophone Africa is particularly relevant to study the metropolitan effect. French colonial rule was 'erected on an ethnocentric assimilationist paradigm that refused to interpret culture as a dynamic process and, accordingly, to incorporate African cultural elements, preferring instead to dismiss, repudiate, and systematically erase African identity' (Thomas, 2007: 9). This implied a model of totally assimilating the native population through the establishment of institutions (educational, administrative, legal, etc.) and systems (financial, infrastructures, etc.) that mirrored those in the home country. This contrasted sharply with the approach of the British colonial administrators who thought 'it was their task to conserve what was good in indigenous institutions and assist them to develop on their own lines' (Crowder, 1964: 198). The contrasting approaches of the two leading colonial powers expressed themselves in distinctly different administrative structures. The assimilative approach of the French was largely implemented through a system of direct rule, while the British largely used a system of indirect rule (Whittlesey, 1937). Lesser colonial powers like the Netherlands (e.g., in Indonesia) and Belgium (e.g., in the Congo), as well as colonial powers whose influence declined much earlier like Spain and Portugal (e.g., in Latin America) provide further opportunities to study the influence of context on the metropolitan effect.

Developing and testing this model would be useful both as an aid to understanding frontier economy firm choices but also as a guide to policy. Given the business and institutional voids associated with the frontier economy environments, including the lack of connectivity to global value chains, it may take more than having special resources or competitive advantages for ambitious African firms to succeed in the international arena. The key to success may well be the resources and capabilities, especially legitimacy, gained from leveraging the well-worn paths of education, migration, and even physical infrastructure to succeed in the former colonial power. In turn, these resources and legitimacy can then be leveraged to support internationalization into other countries, including both neighbors in Africa and emerging and developed countries across the globe.

Finally, the scale and impact of the metropolitan effect is likely to vary substantially across former colonial powers. As we have argued, the evidence suggests that the effects are particularly strong and wide-ranging in the case of Francophone Africa. However, a very large percentage of current emerging and frontier economies are associated with one or other metropolitan center, either through old colonial ties or links generated through various economic and geopolitical spheres of influence. This suggests that the metropolitan effect is likely to apply and provide valuable insights into internationalization of firms from a wide range of country contexts.

(C) 2019 The International Association for Chinese Management Research 


\section{NOTES}

[1] In many ways, this Chinese FDI into Africa mirrors American and European FDI into developing countries during the heyday of imperialism. As analyzed by Hirschman (1968), this FDI (largely in extractive industries) had virtually no linkages to the domestic economy, but where typically tightly integrated with operations in the home country.

[2] Africa accounted for only 2.4\% of global exports and 3.4\% of global imports in 2015 (WTO, 2016). Only 8\% of foreign affiliates in Africa are owned by African entities. Intra-African trade accounts for $11 \%$ of Africa's total trade, compared to a figure of $25 \%$ for Asia and $60 \%$ for Europe (IMF, 2012; Kimenyi, 2016; UNCTAD, 2016). South Africa has had less success than China and India, especially recently. However, we mention South Africa as an example of connectedness to the global economy, an area where its firms continue to lead the rest of Africa. For instance, the top 20 non-financial South African-owned MNEs listed $\$ 50$ billion in foreign assets at the end of 2015, a figure that dwarfs that of any other African country (Bezuidenhout and van Rensberg, 2016). Seventeen of the top 20 African MNEs are based in South Africa (Ford, 2014). Finally, according to a recent study, South Africa was the highest ranking country in Africa in terms of its business systems (Witt et al., 2018).

[3] Interestingly, despite the well-documented political, institutional, and economic challenges in nearly every country in Africa, (Anderson, 2011; Barnard et al., 2017), including for the MENA countries the Arab Spring, none of the firms interviewed cited escape from the accumulated uncertainty about political relations, institutional weakness, or economic challenges (Barnard \& Luiz, 2018) as a central motivation for internationalization - although BGFI's decision to apply for certification in France suggests that the institutional context in Gabon was not serving BGFI well.

\section{REFERENGES}

Anderson, L. 2011. Demystifying the Arab Spring: Parsing the differences between Tunisia, Egypt, and Libya. Foreign Affairs, 90(3): 2-7.

Awate, S., Larsen, M. M., \& Mudambi, R. 2012. EMNE catch-up strategies in the wind turbine industry: Is there a trade-off between output and innovation capabilities? Global Strategy Journal, 2(3): 205-223.

Barnard, H. 2014. Migrating EMNCs and the theory of the multinational. In A. Cuervo-Cazurra \& R. Ramamurti (Eds.), Understanding multinationals from emerging markets: 195 223. New York: Cambridge University Press.

Barnard, H., Cuervo-Cazurra, A., \& Manning, S. 2017. Africa business research as a laboratory for theory-building: Extreme conditions, new phenomena, and alternative paradigms of social relationships. Management and Organization Revieze, 13(3): 467-495.

Barnard, H., \& Luiz, J. M. 2018. Escape FDI and the dynamics of a cumulative process of misalignment and contestation: Stress, strain and failure.Journal of World Business, 53(5): 605-619.

Barnard, H., \& Pendock, C. 2013. To share or not to share: The role of affect in knowledge sharing by individuals in a diáspora. Journal of International Management, 19(1): 47-65.

Beugelsdijk, S., \& Mudambi, R. 2013. MNEs as border-crossing multilocation enterprises: The role of discontinuites in geographic space. Journal of International Business Studies, 44(5): $413-426$.

Bezuidenhout, H., \& van Rensberg, J. 2016. An original ranking of South Africa's global players for 2013-2015. New York: Columbia Center for Sustainable Development.

Birkinshaw, J., Brannen, M. Y., \& Tung, R. L. 2011. From a distance and generalizable to up close and grounded: Reclaiming a place for qualitative methods in international business research. Journal of International Business Studies, 42(5): 573-581.

Bitektine, A. 2011. Toward a theory of social judgments of organizations: The case of legitimacy, reputation, and status. Academy of Management Revieze, 36(1): 151-179.

Boddewyn, J. J. 1995. The legitimacy of international-business political behavior. The International Trade Joumal, 9(1): 143-161.

Boisot, M., \& Meyer, M. 2008. Which way through the open door? Reflections on the internationalization of Chinese firms. Management and Organization Revieze, 4(3): 349-365.

Buckley, P. J. 2018. Internationalisation theory and outward direct investment by emerging market multinationals. Management International Revieze, 58: 195-224. 
Buckley, P. J., Clegg, J., Cross, A., Liu, X., Voss, H., \& Zheng, P. 2007. The determinants of Chinese outward foreign direct investment. Journal of International Business Studies, 38(4): 499518.

Cantwell, J., \& Mudambi, R. 2011. Physical attraction and the geography of knowledge sourcing in multinational enterprises. Global Strategy Journal, 1(3-4): 206-232.

Claasen, C., \& Roloff,J. 2012. The link between responsibility and legitimacy: The case of DeBeers in Namibia. Journal of Business Ethics, 107: 379-398.

Crowder, M. 1964. Indirect rule - British and French style. Africa -Journal of the International African Institute, 34(3): 197-205.

Cuervo-Cazurra, A., \& Genc, M. 2011. Obligating, pressuring, and supporting dimensions of the environment and the non-market advantages of developing-country multinational companies. Journal of Management Studies, 48: 441-455.

Cuervo-Cazurra, A., \& Narula, R. 2015. A set of motives to unite them all? Revisiting the principles and typology of internationalization motives. Multinational Business Revieze, 23(1): 2-14.

Cuervo-Cazurra, A., Narula, R., \& Un, C. A. 2015. Internationalization motives: Sell more, buy better, upgrade and escape. Multinational Business Revieze, 23(1): 25-35.

Darendeli, I. S., \& Hill, TL (2016). Uncovering the complex relationships between political risk and MNE firm legitimacy: Insights from Libya.Journal of International Business Studies, 47 (1): 68-92.

De Soto, H. 2000. The mystery of capital: Why capitalism triumphs in the West and fails everyzehere else. New York: Basic Books.

Dia, M. 1996. Africa's management in the 1990s and beyond: Reconciling indigenous and transplanted institutions. Washington, DC: The World Bank.

Dunning, J. H. 1993. Multinational enterprises and the global economy. New York: AddisonWesley.

Eisenhardt, K. M., \& Graebner, M. E. 2007. Theory building from cases: Opportunities and challenges. Academy of Management Joumal, 50(1): 25-32.

Ekeh, P. 1975. Colonialism and the two 'publics' in Africa: A theoretical statement. Comparative Studies in Society and History, 17(1): 91-112.

Ford, N. 2014. Africa's top 250 companies. African Business, April 29.

Fujita, M., \& Mori, T. 1998. On the dynamics of frontier economies: Endogenous growth or the selforganization of a dissipative system? Annals of Regional Science, 32(1): 39-62.

Gann, L. H., \& Duignan, P. 1967. The burden of empire: An appraisal of Western colonialism in Africa south of the Sahara. Stanford, CA: Stanford University Press.

George, G. 2015. Expanding context to redefine theories: Africa in management research. Management and Organization Revieze, 11(1): 5-10.

George, G., Corbishley, G., Khayesi, J. N. O, Haas, M. R., \& Tihanyi, L. 2016. Bringing Africa in: Promising directions for management research. Academy of Management Journal, 59(2): 377-394.

Henisz, W. J., Dorobantu, S., \& Nartey, L. J. 2014. Spinning gold: The financial returns to stakeholder engagement. Strategic Management Journal, 35: 1727-1748.

Ipemed. 2016. Monograph of co-production companies: Misfat. Institut de Prospective Economique du Monde Mediterraneen, 16 February.

IMF. 2012. Direction of Trade Statistics. Washington DC: International Monetary Fund.

Johanson, J., \& Vahlne, J.-E. 1977. The internationalization process of the firm: A model of knowledge development and increasing foreign market commitments. Journal of International Business Studies, 8(1): 23-32.

Johanson, J., \& Vahlne, J.-E. 2009. The Uppsala internationalization process model revisited: From liability of foreignness to liability of outsidership. Journal of International Business Studies, 40(9): 1411-1431.

Khanna, T., \& Palepu, K. 2013. Winning in emerging markets: A road map for strategy and execution. Boston, MA: Harvard Business Press.

Kimenyi, M., Lewis, Z., \& Routman, B. 2016. Introduction: Intra-African trade in context. Washington DC: The Brookings Institution.

Kostova, T., Roth, K., \& Dacin, M. T. 2008. Institutional theory in the study of multinational corporations: A critique and new directions. Academy of Management Revieze, 33(4): 994 1006.

Kothari, T., Kotabe, M., \& Murphy, P. 2013. Rules of the game for emerging market multinational companies. Journal of International Management, 19: 276-299. 
Kumaraswamy, A., Mudambi, R., Saranga, H., \& Tripathy, A. 2012. Catch-up strategies in the Indian auto components industry: Domestic firms' responses to market liberalization. Journal of International Business Studies, 43(4): 368-395.

Kuznetsov, Y. 2006. Diaspora networks and the international migration of skills: How countries can draw on their talent abroad. WBI Development Studies. Washington, DC: World Bank.

Lee, A., \& Schultz, K. 2012. Comparing British and French Colonial legacies: A discontinuity analysis of Cameroon. Quarterly Journal of Political Science, 7: 1-46.

Levin, D. Z., \& Barnard, H. 2013. Connections to distant knowledge: Interpersonal ties between more- and less-developed countries. Journal of International Business Studies, 44(7): 676-698.

Lewin, A. Y., Massini, S., \& Peeters, C. 2009. Why are companies offshoring innovation? The emerging global race for talent. Journal of International Business Studies, 40(6): 901-925.

Lorenzen, M., \& Mudambi, R. 2013. Clusters, connectivity and catch-up: Bangalore and Bollywood in the global economy. Journal of Economic Geography, 13(3): 501-534.

Lundan, S., \& Jones, G. 2001. The Commonwealth Effect and the process of internationalization. The World Economy, 24(1): 99-118.

Luo, Y., \& Tung, R. L. 2018. A general theory of springboard MNEs. Journal of International Business Studies, 49(2): 129-152.

Makino, S., \& Tsang, E. W. K. 2011. Historical ties and foreign direct investment: An exploratory study. Journal of International Business Studies, 42(4): 545-557.

Mayer, S. D., Harima, A., \& Freiling, J. 2015. Network benefits for Ghanaian diaspora and returnee entrepreneurs. Entrepreneurial Business and Economics Revieze, 3(3): 95-122.

Merriam-Webster. 2018. 'Metropolitan'. [Cited 21 November 2018]. Retrieved from URL https:// www.merriam-webster.com/dictionary/metropolitan

Meyer, K. E., Mudambi, R., \& Narula, R. 2011. Multinational enterprises and local contexts: The opportunities and costs of multiple embeddedness. Journal of Management Studies, 48(2): 235-252.

Mody, A. 2004. What is an emerging market? Working Paper 04/177, IMF : Washington DC.

Moghaddam, K., Sethi, D., Weber, T., \& Wu, J. 2014. The smirk of emerging market firms: A modification of the Dunning's typology of internationalization motivations. Journal of International Management, 20(3): 359-374.

Mudambi, R. 1998. Review of international financial management. Joumal of Finance, 53(3): $1194-1197$.

Mudambi, R. 2008. Location, control and innovation in knowledge intensive firms. Journal of Economic Geography, 8(5): 699-725.

Osborn, E. 2003. Circle of iron: African colonial employees and the interpretation of colonial rule in French West Africa. Joumal of African History, 44(1): 29-50.

Pant, A., \& Ramachandran, J. 2012. Legitimacy beyond borders: Indian software services firms in the United States, 1984 to 2004. Global Strategy Journal, 2(3): 224-243.

Peng, M. W., Wang, D., \& Jiang, Y. 2008. An institution-based view of international business strategy: A focus on emerging economies. Journal of International Business, 39(5): 920-936.

Ramamurti, R. 2012. Competing with emerging market multinationals. Business Horizons, 55, 241-249.

Rangan, S., \& Drummond, A. 2004. Explaining outcomes in competition among foreign multinationals in a focal host market. Strategic Management Journal, 25(3): 285-293.

Riddle, L., Hrivnak, G. A., \& Nielsen, T. M. 2010. Transnational diaspora entrepreneurship in emerging markets: Bridging institutional divides. Journal of International Management, 16 : 398-411.

S\&P Global. 2017. S\&P Global BMI, S\&P/IFCI Methodology. New York: Standard \& Poor's.

Sarasvathy, S., Kumar, K., York, J. G., \& Bhagavatula, S. 2014. An effectual approach to international entrepreneurship: Overlaps, challenges, and provocative possibilities. Entrepreneurship, Theory and Practice, 38(1): 71-93.

Saxenian, A. 2005. From brain drain to brain circulation: Transnational communities and regional upgrading in India and China. Studies in Comparative International Development, 40 (2): $35-61$.

Saxenian, A. 2007. The new Argonauts: Regional advantage in a global economy. Boston: Harvard University Press. 
Scherer, A. G., Palazzo, G., \& Seidl, D. 2013. Managing legitimacy in complex and heterogeneous environments: Sustainable development in a globalized world. Journal of Management Studies, 50(2): 259-284.

Schotter, A., \& Abdelzaher, D. 2013. The boundary spanning effects of the Muslim diaspora on the internationalization processes of firms from organization of Islamic conference countries. Joumal of International Management, 19: 82-98.

Schotter, A., Mudambi, R., Doz, Y., \& Gaur, A. 2017. Boundary spanning in global organizations. Journal of Management Studies, 54(4): 403-421.

Shinn, D. H., \& Eisenman, J. 2012. China and Africa: A century of engagement. Philadelphia: University of Pennsylvania Press.

Stasavage, D. 1997. The CFA franc zone and fiscal discipline.Joumal of African Economies, 6 (1): 132-167.

Stevens, G., \& Newenham-Kahindi, A. 2017. Legitimacy spillovers and political risk: The case of FDI in the East African community. Global Strategy Journal, 7(1): 10-35.

Suchman, M. C. 1995. Managing legitimacy: Strategic and institutional approaches. Academy of Management Revieze, 20(3): 571-610.

Suddaby, R., \& Greenwood, R. 2005. Rhetorical strategies of legitimacy. Administrative Science Quarterly, 50(1): 35-67.

Thomas, D. 2007. Black France: Colonialism, immigration and transnationalism. Bloomington and Indianapolis: Indiana University Press.

UNCTAD. 2016. World Investment Report. UNCTAD: Geneva.

Vahlne, J.-E., \& Johanson, J. 2017. From internationalization to evolution: The Uppsala model at 40 years. Journal of International Business Studies, 48(10): 1087-1 102.

Wang, S., \& Cuervo-Cazurra, A. 2017. Overcoming human capital voids in underdeveloped countries. Global Strategy Joumal, 7(1): 36-57.

Whittlesey, D. 1937. British and French colonial technique in West Africa. Foreign Affairs, 15(2): 362-373.

Williams, D., \& Grégoire, D. 2013. Seeking commonalities or avoiding differences? Re-conceptualizing distance and its effect on internationalization decisions. Journal of Intermational Business Studies, 46: 253-284.

Witt, M., de Castro, L., Amaeshi, K., Mahroum, S., Bohle, D., \& Saez, L. 2018. Mapping the business systems of 61 major economies: A taxonomy and implications for varieties of capitalism and business systems research. Socio-Economic Revieze, 16(1): 5-38.

WTO. 2016. World Trade Statistical Revieze. Geneva: World Trade Organization.

$\mathrm{Xu}$, D., \& Meyer, K. E. 2013. Linking theory and context: 'Strategy research in emerging economies' after Wright et al. (2005). Journal of Management Studies, 50(7): 13221346.

Yin, R. K. 2002. Case study research: Design and methods. Thousand Oaks: SAGE Publications.

Zook, M., \& Brunn, S. 2005. Hierarchies, regions, and legacies: European cities and global commercial passenger air travel. Joumal of Contemporary European Studies, 13(2): 203-220.

Tah Ahmed Meouloud (tah.ahmed.meouloud@temple.edu) is a Senior Economist and an Independent Consultant who has taught at the University of Nouakchott in Mauritania and Sorbonne University in France. He has a Master's Degree in Economics from the University of Nouakchott in Mauritania, a Master's Degree of Research in International Economic Development from the Sorbonne, and a DBA from Temple University.

Ram Mudambi (ram.mudambi@temple.edu) is the Frank M. Speakman Professor of Strategy at the Fox School of Business, Temple University. He is a Fellow of the Academy of International Business and the European International Business Association. He has served as an Associate Editor of the Global Strategy Fournal (GSJ) (2010-2013) and an Area Editor at the Fournal 
of International Business Studies (JIBS) (2013-2016). He is currently a co-editor of GSJ and an area editor at the Fournal of International Business Policy. His work has appeared in the Fournal of Political Economy, the Fournal of Economic Geography, the Strategic Management Fournal, JIBS, Harvard Business Review, MIT Sloan Management Review, California Management Review, among many others. He serves on the editorial boards of numerous journals. His media appearances include National Public Radio, the New York Times, the Atlantic Magazine, the Philadelphia Inquirer as well as numerous local newspaper, TV and radio stations. He holds an M. Sc.(Econ) from the London School of Economics and a $\mathrm{PhD}$ from Cornell University.

TL Hill (tl.hill@temple.edu) is an Associate Professor of Strategic Management, Managing Director of both the Temple University Fox Management Consulting Practice and Fox Translational Research Center. TL's research interests include the governance of knowledge intensive organizations and social ventures, the ways networks span organizational boundaries, and the social and institutional context of international business. He has served on the Editorial Board of the Academy of Management Review is co-author of more than 30 commissioned reports and peer-reviewed publications. His work has appeared in the Fournal of International Business Studies and the Fournal of International Management, among others. He received his $\mathrm{PhD}$ from Temple University.

Manuscript received: January 17, 2017

Final version accepted: November 11, 2018 (number of revisions - 4)

Accepted by: Deputy Editor Helena Barnard 